\title{
RIGHT-WING AND LEFT-WING POPULIST PARTIES AS A THREAT TO MODERN LIBERAL DEMOCRACIES
}

Keywords: populism, democracy, liberalism, populist parties, parliamentarism.

\begin{abstract}
The article analyses modern populism as a challenge to liberal democracy in terms of the activities of right-wing and left-wing political parties. An important factor in the growth of populism is the lack of effectiveness of constitutionalism and other formal limited institutions, procedures to ensure the principles of people's sovereignty, democracy, justice, guarantee the interests of the majority in the modern world.

It is noted that populism emerged in the late 19th century as a social movement, ideology, and political activity, and since then has firmly taken its place in the political consciousness of the masses, gaining new features and intensifying at times when countries are experiencing turning points in their history. The main factors in the growth of populism include the insufficient effectiveness of the institutions of indirect democracy in modern consolidated democracies. Another reason for the rise of populism is related to the tendency of ideological deradicalization, which manifested itself in the activities of different parties.

Today, populism does not have a developed fundamental theoretical background and conceptual texts like nationalism and conservatism. However, it has a holistic structure as a political phenomenon and a set of ideological positions. The goal of modern populism is the introduction of "illiberal democracy" - a government that ensures smooth transformation of people's preferences into public policy (unlike liberal democracies, which are almost always hindered by certain obstacles to responding effectively to pressing problems). From this point of view, populism is not a threat to democracy as such, but the leading liberal version of democracy.
\end{abstract}

1 Postgraduate Student at the Department of Political Science, Taras Shevchenko National University of Kyiv, maksymburdiuh@gmail.com. ORCID: 0000-0003-00173588 . 
The possibilities of constitutionalism are treated with scepticism in the populist ideology, as formal, limited institutions and procedures prevent the majority from executing their will. Liberal democracy is not strong enough and constantly needs strengthening elements in response to new challenges and threats. But liberal democracy, more than any other political form, contains the potential for development, a synergistic resource, and the power of self-correction. A strong parliament and a developed civil society remain effective counterweight to populism.

\section{INTRODUCTION}

Since the actualization of the problem of populism in political science, there have been attempts to capture the unique features of this phenomenon. They remained at the descriptive level. One of the current trends is reducing the degree of rationality of political activity. It is manifested, particularly, in the fact that citizens make decisions based on emotions. In the context of the growing threatening effects of populism, we consider it unnecessary to concentrate on its positive functions. For instance, such an attractive feature as that communication is done in a language understood by most citizens. The phenomena of left-wing populist parties and Eurosceptic ideologues (right-wing populist parties), which represent the so-called "political alternative" were studied on the example of several European parties.

The research aims to perform a comprehensive political analysis of the populist parties phenomenon in the context of threats to the development of liberal democracy. The defined research task is to determine the influence of language on people's behaviour as well as the ability of language to be a clear tool of political action. Theoretical developments of Ukrainian researchers on the influence of text on behaviour and consciousness of people in different political systems, the interdependence of language and politics, in general, give an idea of populism as a product of political communication. Another task of this research is to analyse the reason for the growing power of populist leaders as well as regional differences and trends in the development of populist movements.

Among the methods used for this research, it is important to mention the comparative-historical method, used to define and evaluate current trends in populism. The hypothetical-deductive method was used to 
predict the consequences of certain occurrences. The method of analysis was used throughout the whole research to compile and characterize the variety of facts and informational points regarding the topic of research.

Potential and further perspectives of the research lie in broadening the geographical area of focus as well as analysis of the newer methods, tools, and subterfuge of populist activists in the political area.

\section{THEORETICAL GROUNDS AND NATURE OF MODERN POPULISM}

Modern populism is the result of the transformation of politics into marketing. Of course, a populist represents himself primarily as a representative of „small" honest people whose interests are underrepresented. Besides, it offers simple solutions to complex problems. It also, however, creates a threat to liberal democracy's political structure (Galston, 2018).

The populist worldview is simple: in general, the world is divided into broad groups of decent „ordinary people” and a corrupt „elite.” Thus, a populist fuels his political activity with anti-elitist sentiments, conspiracy theories of "people in power" and dissatisfaction with the trend of globalization. In addition, populism fosters mistrust because it is critical to fostering the low perception of the legitimacy of the ruling elite and the institutions in which it operates, even if those institutions are democratic. That is why populist politicians are coming to power quickly. Today, the world has many reasons for wanting to hear populists (Kaltwasser, 2013). It is becoming increasingly complex, the traditional political field is changing, and political parties are less and less based on fundamental ideological beliefs. Furthermore, the decades-old, worn infrastructure of traditional political parties readily crumbles. These parties lose cells, activists, ideologies, and sources of funding, thus freeing up space for new forces.

Moreover, the political decisions that need to be made often go beyond the traditional division between the „left” and the „right”. For example, in today's world, many countries have problems with growing inequality between rich and poor. Forbes estimates that the number of billionaires in the world has quadrupled in the last two decades. 
According to the research, performed by OXFAM International, the wealth of 2153 billionaires is more than the wealth of $60 \%$ of the poorest people of the world, which illustrates a tremendous gap in the distribution of prosperity. (Ratcliff \& Thériault, 2020). While the rich mostly benefit from globalization and its „openness," the poorest often lose because competition in the labour market increases through migrant worker policies. The classic „left” (socialist) parties advocate social equality and openness to the world; the „right” (patriotic), for national identity and protection from the challenges of the outside world.

We emphasize that „populist consciousness is a special democratic component of political culture, which reflects the desire of the general public to effective and direct participation in the political process" (Demyanenko, 2017).

With the growing number and importance of the liberal constraints of the democratic majority, the system is moving towards post-democracy. When the number of liberal restrictions decreases or when there is a movement in the opposite direction to direct democracy, state systems move towards populism. But every action stimulates a reaction. As more power has shifted to liberal institutions in recent years, and democratic coalitions have become weaker, as a result, there has been an increasing expression of populism in politics, which focuses on ignoring the will of the electorate. The table below demonstrates this in the form of a meaningful socio-scientific comparison (Table 1).

Table 1. Context of the emergence of populism analysis in the modern political process

\begin{tabular}{|l|l|l|}
\hline \multicolumn{2}{|c|}{ Post-democracy $\leftrightarrow$} & \multicolumn{1}{c|}{ Majority liberal democracies $\leftrightarrow$ Populism } \\
\hline Bill of Rights & $\begin{array}{l}\text { Majority electoral system of } \\
\text { relative majority }\end{array}$ & $\begin{array}{l}\text { Participatory practice } \\
\text { (participatory) democracy, } \\
\text { referendum }\end{array}$ \\
\cline { 3 - 3 } International courts of law & & Elected judges \\
\hline PR (public relations) & $\begin{array}{l}\text { Bicameralism and the veto of } \\
\text { one chamber of parliament } \\
\text { on the legislation of another }\end{array}$ & $\begin{array}{l}\text { Federalism and confedera- } \\
\text { lism }\end{array}$ \\
\hline UN monitoring & & Recall of the deputy \\
\hline
\end{tabular}




\begin{tabular}{|l|l|l|}
\hline \multicolumn{1}{|c|}{ Post-democracy $\leftrightarrow$} & Majority liberal democracies $\leftrightarrow$ Populism \\
\hline Constitutional Court & Developed parliamentarism & $\begin{array}{l}\text { An effective tool of impeach- } \\
\text { ment }\end{array}$ \\
\hline $\begin{array}{l}\text { Strength of law, equality of } \\
\text { rights }\end{array}$ & Citizenship concept & $\begin{array}{l}\text { The concept of citizenship, } \\
\text { cultural concepts of citizen- } \\
\text { ship, post-civil generation }\end{array}$ \\
\hline Rich - poor & $\begin{array}{l}\text { Very poor - very rich, margi- } \\
\text { nalization of the lower social } \\
\text { classes }\end{array}$ & $\begin{array}{l}\text { Overcoming social inequality, } \\
\text { ensuring full employment } \\
\text { and decent wages (ideally) }\end{array}$ \\
\hline
\end{tabular}

\section{ANALYSIS OF CURRENT POSITIONS OF POPULIST FORCES IN WESTERN DEMOCRACIES}

In 2016, Donald Trump was a star of populism in Western countries. However, the midterm elections in the United States in November 2018 showed that the situation is not cloudless for Republicans. They lost control of the House of Representatives in the elections. Therefore, Trump, a prototypical right-wing politician, lost some room for manoeuvre. His rating dropped slightly but remained high. According to the ratings of various departments in 2019,52\% of Americans did not support the policy of the president, and $42 \%$ supported it. Compared to the sharp drop in the rating of E. Macron in France or some other leaders of democratic countries, this can be considered a success. And this is another mystery of the populists: despite the excessive simplicity of some of their ideas, today they are able not only to gain power but also to retain it.

In today's world of divided groups, the space for rational politics is shrinking: one cannot win by solving everyone's problems. One can win knowing how to convince those who will believe in them. For the world at large, 2017 and 2018 were years of realization that the consequences of simple decisions can be very complex. More than two years after the fateful vote to leave the European Union (EU), the British had to decide how and under what conditions they would leave the union. Members of the 
House of Representatives have refused to vote in favour of Britain's agreement with the EU, which was backed by Prime Minister Theresa May. Populist calls to leave the EU were aimed at solving all of Britain's problems: issues with migrants, finances, and legislation defined by Brussels. May's compromise decision was criticized on all sides as not strong enough; it was noted that Britain would become a colony of Brussels. Other arguments included suspicions that Britain would lose the European market.

Populism is also on the rise in southern Europe, with conditions of distrust in institutions and a strong tendency to personify politics: the identification of the political process with the image of a certain leader. This creates a favourable situation for populists. On the other hand, in Italy after the Second World War, the positions of the "left" parties were strong and today have been transformed into support for "anti-systemic" movements (Romanyuk, 2007).

2018 was a year of populist triumph in Italy. In the early parliamentary elections in March 2018, two populist political forces came to power at the same time: the Northern League and the Five Star Movement. It was they who formed the parliamentary coalition. The Northern League, led by Matteo Salvini, is a classic example of a right-wing populist party that capitalizes on migration issues and takes a strong, sometimes aggressive stance on the established political establishment.

Left and centre-left populist parties have also emerged in Europe. In Italy, the Movimento 5 Stelle (M5S) comedian Beppe Grillo won the largest number of seats in the 2013 House of Representatives. In the June 2016 municipal elections, Virginia Raji, a candidate from the Five Star Movement, received $67 \%$ of the vote and was elected mayor of Rome.

The rise to power of Italian populists strengthened the position of Eastern European populists. If a few years ago such figures as Viktor Orban in Hungary, Milos Zeman, and Andriy Babis in the Czech Republic, and Jaroslav Kaczynski in Poland were perceived as marginal, today they can talk about creating a populist front in Europe as a whole. Political strategist Steve Bannon, seeking to unite populist movements in Europe, wants populist parties to get one-third of the votes in the next European election. One-third may be too ambitious, but given the grow- 
ing position of populists in countries such as France, Germany, and even Sweden, it is not altogether impossible.

The case of progress of populism on the European continent has considerable methodological potential. It is important to try to predict whether the populists will be able to retain power where they have gained it. The history of the last few years shows that populists are far from accidental and not a temporary phenomenon or misunderstanding. Modern populists know how to meet people's needs and can stay true to them. They often manipulate emotions or treat others with contempt, but their messages are fully in line with the real concerns of citizens. Further on other factors in the context of characterizing the political attributes of modern liberal democracies have to be analysed. Immigration control is one example of a policy that is emphasized in many countries. European integration is an example, especially in the UK, of the direction of the public policy pursued by default or behind the curtain. This uncodified and informal approach follows the concepts of a constitutional convention. The longer such a veil of public policy-making remains unnoticed in this respect, the more elected or parliamentary majorities will cease to be decision-makers and become one of several stakeholders in the roundtable. Majority democracy in these conditions mutates into what the Hudson Institute John Fonte calls post-democracy, in which the elites and institutions they control have more power than the voters and their elected representatives.

In Latin America, 2018 was marked by the two populist presidents coming to power - the right-wing Bolsonaro in Brazil and the left-wing Obrador in Mexico. 2019 was a crucial year for Asia's two largest democracies. In India, Narendra Modi, today the prime minister and what the Western press often calls populist, has a good chance of remaining in office after the spring election. In Indonesia, the current populist president, Joko Vidodo, has a good chance of winning. Such a wave of growing populist sentiments in the world creates favourable opportunities for case studies of the analysis of populist policies in different countries, regions, and civilizations.

Protest parties have always existed, they can overcome the status of marginalized and acquire the status of "political alternative" parties, offer 
the electorate an alternative system of values and, accordingly, an alternative order. But these parties will be popular only if society and the state face multifaceted negative ethnopolitical and socio-economic pressures.

At the same time, in some countries, including Belgium, Germany, Greece and France, traditional political forces continue to support the existence of a fairly strong "sanitary border" around populist parties, i.e. a situation in which regardless of the level of electoral support for the populists (as well as their presence in the legislature), all major political forces categorically avoid cooperating with them. Parties in this situation are in fact "pariah parties".

\section{CURRENT AND FUTURE CHALLENGES TO LIBERAL DEMOCRACY ENFORCED BY POPULISTS}

One of the factors determining the threat of populism to liberal democracies is Euroscepticism - a collective designation of protests and ideas that are reduced to a critical attitude toward the forms, pace and goals of European integration, as well as related processes in socio-economic and ethnocultural spheres. Another factor already mentioned in passing is right-wing populism in modern Europe, a special political style of party behaviour aimed at winning the sympathy of the protesting and passive electorate by offering simplified solutions to the most difficult problems and opposing some ethnic and social groups.

The populist challenge to liberal democracy can be seen as an emotional frustration over economic expectations, dissatisfaction with artificial political rules and unfulfilled political promises, and a threat to the physical and cultural security of the people as a source of power.

In this discussion, it is necessary to dwell on the theoretical justification of the concept of "people." In a general sense, the people are all citizens, regardless of religion, customs and the duration of their relationship with the state, through the institution of citizenship. The people are a community that has a common civil status. There is also an ethnic understanding of the people as an association of those who come from the same ancestors, speak the same language, profess the same religion, are tied to 
the same principles of government, and who are very similar in their manners and customs (Inglehart \& Norris, 2016). Historically, right-wing populists have emphasized the importance of common ethnicity and common background, while left-wing populists have often defined people by class, excluding those with wealth and power. Recently, a third definition has entered the public debate - real people (ordinary), who, unlike cultural elites (noble status), do not have refined aristocratic manners and habits.

In the context of people's sovereignty, the division of the country's population into "real" people and "others" means that some parts of the population - "others" - do not deserve to participate in self-government. This violates the principle of inclusion, which is important for democracy.

The populist definition of people presupposes that people must make a single judgment, a special agreed will. It is difficult to imagine even in an unstructured society; different social groups will have different interests, values, and multiple opinions. Populism is in some ways opposed to pluralism and, consequently, to democracy. Imposing the assumption of uniformity in the context of the reality of diversity somewhat distorts the facts and eliminates the desire to find fair conditions for living together as free, equal, but also different citizens.

Modern autocratic regimes do not have as much ideological appeal as fascism and communism once did. But at the same time, the current woes of liberal democracy are deep and pervasive. Overcoming them will require intellectual clarity and political leaders who are willing to take risks, serving the long-term interests of their countries. The human factor, human choice, and leadership human resources, not the historical inevitability, will determine the fate of liberal democracy (Amy \& Welzel, 2017)

The opinion of other well-known theorists should be taken into account. They emphasize the exact opposite and argue that the populist challenge to democracy is serious and must be immediately assessed as a threat."We simply do not have anything like a theory of populism", - says Muller in his book on populism (Müller, 2016). However, both his as well as the current researches defined common populist practices. Further on, at present, the democratic community supports policy changes that give it hope for a better future. Left unsatisfied, the demands of the general 
public, framed in emotional rather than pragmatic or realistic considerations, can escalate into protest pressure for regime change. Using the power of the media and the power of the rostrum, charismatic populists challenge the old elite, but populists are not always able to offer a decent alternative.

In general, political battles over the distribution of wealth and income flows are much easier to resolve than disputes over morality, ethnicity, citizenship, and loyalty, which we see in the United States as "toxic.. The Brexit referendum is almost a parable about the necessary and valuable use of populism in politics in certain situations. Opposition to Britain's membership in the European Union has never ceased to be a significant area of political thought. The controversy lasted at the level of about a third of the respondents, sometimes reactivating, throughout the period since 1975. But because the leadership of the Conservative and Labor parties strongly supported the EU, Eurosceptic public opinion in Britain was rarely at the centre of political debate. As soon as the real public debate was conducted according to the rules of media neutrality, the Eurosceptic position became more important than expected and even grew. In other words, "populism" helped to unleash genuine and entrenched democratic sentiments in Britain that might otherwise have been suppressed.

\section{CONCLUSIONS}

Practically, populism plunges democratic societies into endless conflicts, threatens the rights of minorities, and promotes authoritarian sentiment. Both right-wing and left-wing populist parties pose the same threat to modern liberal democracy. Their activities threaten liberal democracy from within, actualizing the public discourse of reducing the level of ethnic, religious or national freedoms.

Factors contributing to the success of populist parties include citizens' awareness that the prevailing political norms, which put forward and protect the country's leading strata, are beginning to run counter to their hopes, fears and concerns. Populist parties use these contemptuous fears in their slogans and build their policies on them, "inciting the people 
against an elite" that does not agree to compromises. By doing so, they become a catalyst for political change that is unconstructive for the development of democracy. An effective counterweight to populism remains a strong parliament and a developed civil society. Potential and further perspectives of the given research lie in broadening the geographical area of focus as well as analysis of the newer methods, tools and subterfuge of populist activists in the political area.

\section{BIBLIOGRAPHY:}

Amy, C., Welzel, Ch. (2017). The Myth of Deconsolidation: Rising Liberalism and the Populist Reaction. ILE Working Paper Series, 10, University of Hamburg, Institute of Law and Economics (ILE), Hamburg.

Demyanenko, M. (2017). Moralno-etichniy aspect populizmu. Downloaded from: http:// naukajournal.org/index.php/Paradigm/article/view/480

Galston, W.A . (2018). The Populist Challenge to Liberal Democracy. Journal of Democracy, 29, 5-19.

Inglehart, R., Norris, P. (2016). Trump, Brexit, and the Rise of Populism: Economic HaveNots and Cultural Backlash. Downloaded from: https://papers.ssrn.com/sol3/papers. cfm?abstract_id $=2818659$.

Jay J. (2018). The Federalist Papers, 2. Downloaded from: http://avalon.law.yale.edu/18 ${ }^{\text {th }}$ century/fed02.asp.

Kaltwasser, C. (2013). The Responses of Populist to Dahl's Democratic Dilemmas, Political Studies. 